\title{
DIÁLOGO DA ALMA
}

Aline Maria Magalhães é doutoranda no Programa de Pós-Graduação em Estudos Literários da Universidade Estadual Paulista, Faculdade de Ciências e Letras de Araraquara/SP.

E-mail: alinemmo@gmail.com

Percebe o silêncio?

Nele há mais vida

Que na cidade cheia de pessoas, carros, ruídos, vozes

Nele há mais sinceridade

Que numa conversa entre amigos

Porque no silêncio ecoa

A sinceridade dos pensamentos,

O sopro mais puro de vida

O diálogo da alma.

SINAL

Essa ruga em meu rosto

Não é da idade

É desgosto,

Desencanto

Lamento

Prantos

E noites em branco...

Ela é um sinal

Não do tempo decorrido

Mas do tempo mal vivido

Dos dissabores da vida

Que passam deixando sua marca

Não no corpo

Mas na alma. 


\title{
OS CACOS DE MINHA HISTÓRIA
}

\author{
Vaga lembrança \\ de uma memória em farrapos. \\ Fiapos, apenas \\ fios soltos da memória, \\ vão costurando histórias \\ que formam uma colcha de retalhos. \\ Sem forma exata, \\ sem cores vivas. \\ Apenas uma colcha velha \\ para se cobrir nos dias frios. \\ Sem graça ou harmonia, \\ apenas para aquecer, \\ para não perceber \\ os cacos de minha história.
}

